Article

ULGUIM, A.R. ${ }^{*}$

SILVA, B.M. ${ }^{2}$

AGOSTINETTO, D. ${ }^{3}$

AVILA NETO, R.C. ${ }^{1}$

ZANDONÁ, R.R. ${ }^{3}$

\section{Resistance MapPing OF The Genus Cyperus in Rio Grande do Sul and Selection Pressure Analysis}

\author{
Mapeamento da Resistência do Gênero Cyperus no Rio Grande do Sul e Análise \\ da Pressão de Seleção
}

\begin{abstract}
Among the species of the genus Cyperus occurring in paddy rice, C. esculentus, C. difformis and C. iria are the most important, and the latter two are reported as resistant to herbicides in Rio Grande do Sul (RS). The aim of this work was to characterize and mapping the occurrence of resistant plants of the genus Cyperus in areas of paddy rice in RS State, and to analyze the agronomic factors that interfere in the resistance selection. Seeds from individual plants were harvested in the 2014/15 crop, characterized as control failures by the application of acetolactate synthase inhibitors (ALS), totaling 43 samples. At the time of collection, the grower was inquired on aspects related to the management of weeds in the crop. Seeds were germinated in BOD and when seedlings were in two leaves stage they were transplanted into $0.3 \mathrm{~L}$ pots containing substrate. When the plants had 4-6 leaves, imazapyr + imazapic was spray at the registration rate. Thirty days after application, control of the tested biotypes was evaluated, converting the data to binary scale, where zero (0) and one (1) correspond to susceptibility and resistance, respectively. The agronomic factors that denote the high selection pressure of resistant biotypes are the consecutive use of Clearfield ${ }^{\circledR}$ technology, the use of higher doses than the registration and the low crop rotation adoption. Although not mentioned as one of the main weeds, it is observed that almost half of the samples collected from plants of the genus Cyperus are resistant to the ALS inhibitors, distributed in almost all the growing regions.
\end{abstract}

Keywords: acetolactate synthase, Cyperus esculentus, C. iria, C. difformis, irrigated rice.

RESUMO - Entre as espécies do gênero Cyperus ocorrentes na lavoura de arroz, destacam-se $\boldsymbol{C}$. esculentus, $\boldsymbol{C}$. difformis e $\boldsymbol{C}$. iria, sendo as duas últimas relatadas como resistentes a herbicidas no Rio Grande do Sul (RS). Os objetivos deste trabalho foram caracterizar e mapear a ocorrência de plantas resistentes do gênero Cyperus em áreas de arroz irrigado no RS e analisar os fatores agronômicos que interferem na seleção da resistência. Foram realizadas coletas de sementes de plantas individuais na safra de 2014/15, caracterizadas como falhas de controle pela aplicação de inibidores da acetolactato sintase (ALS), totalizando 43 amostras. Por ocasião da coleta, o produtor foi arguido sobre aspectos relacionados ao manejo de plantas daninhas na lavoura. Na sequência, as sementes foram germinadas em $B O D$ e, quando as plântulas estavam em estádio de até duas folhas, transplantadas para vasos com capacidade para $0.3 \mathrm{~L}$ contendo substrato. Quando as plantas apresentavam entre 4 e 6 folhas, foi aplicado imazapyr+imazapic na dose de registro. Aos 30 dias após a aplicação, foi avaliado controle dos biótipos testados, convertendo-se os dados em escala binária, em que zero (0) e um (1)

${ }^{1}$ Universidade Federal de Santa Maria, Santa Maria-RS, Brazil; ${ }^{2}$ Biotrigo Genética, Passo Fundo-RS, Brazil; ${ }^{3}$ Universidade Federal de Pelotas, Pelotas-RS, Brazil. 
correspondem a suscetibilidade e resistência, respectivamente. Os fatores agronômicos que denotam a alta pressão de seleção de biótipos resistentes são o uso consecutivo da tecnologia Clearfield ${ }^{\circledR}$, o uso de doses superiores à de registro e a baixa adoção de rotação de culturas. Mesmo não sendo citada como uma das principais plantas daninhas, observa-se que quase a metade das amostras coletadas de plantas do gênero Cyperus são resistentes aos inibidores da ALS, distribuídas na quase totalidade das regiões de cultivo.

Palavras-chave: acetolactato sintase, Cyperus esculentus, C. iria, C. difformis, arroz irrigado.

\section{INTRODUCTION}

Weeds are responsible for crop yield losses mainly due to the competition for environmental resources. Among monocotyledonous plants, those of the Cyperaceae family are of great importance because of their intensive presence in many regions around the world and large number of species, approximately 3,000. About 220 species are reported as weeds and approximately $42 \%$ belong to the genus Cyperus (Kissmann, 2007).

Among the species of the genus Cyperus, C. rotundus L., C. esculentus L., C. difformis L., C. ferax Rich., and C. iria L. stand out, being important in irrigated rice (Oryza sativa L.) fields of Rio Grande do Sul and Santa Catarina. These species can cause irreparable damage to crop performance, causing yield losses in irrigated rice around $50 \%$ in the presence of 200 plants m$^{-2}$ of C. esculentus, which points to the need to adopt management measures of them in the early stages of cultivation in order to avoid compromising production (Agostinetto et al., 2016).

The species Cyperus iria also presents importance since, in addition to direct negative aspects of competition for environmental resources, it can promote rice lodging or also hamper harvesting, affecting crop profitability (Chauhan and Johnson, 2010). Moreover, the interference of cultivated rice on the species promotes a reduction in the growth of $C$. iria, reducing its competitive ability. However, management measures are necessary for effective control.

The management of plants of the genus Cyperus is carried out mainly by means of chemical control. Thus, excessive use of this method selected weeds resistant to acetolactate synthase (ALS) inhibiting herbicides in areas of irrigated rice in Brazil (Chapinotto et al., 2017). Among the plants of the Cyperaceae family, resistant biotypes of Fimbristylis miliacea (L.) Vahl, C. difformis, and C. iria (Heap, 2018) are known. However, even with the confirmation of resistance of these plants, little is known about the range and factors that favor the occurrence of resistant biotypes in the State of Rio Grande do Sul (RS), as well as the predominance of the species.

The knowledge of factors that interfere with the selection of resistant weeds, as well as those that influence the population of species in cultivated areas, is an important tool that assists in proposing appropriate management strategies. There are few studies evaluating the distribution of weeds in rice production areas of RS, especially those of the Cyperaceae family. In this sense, this study hypothesized that there are biotypes of plants of the genus Cyperus resistant to ALS inhibitors in all the producing regions of RS and that management practices adopted by producers have a high selection pressure for resistance. Thus, the objectives were to characterize and map the occurrence of resistant plants of the Cyperaceae family in areas of irrigated rice in RS and analyze the agronomic factors that contribute to the selection of resistance.

\section{MATERIAL AND METHODS}

The study was conducted between the growing seasons of 2014/15 and 2015/16. The first part was the collection of seeds from plants of the genus Cyperus and application of questionnaires to farmers, while the second part consisted of an experiment to identify the resistant biotypes. In order to collect seeds of biotypes with suspected resistance, three cotton bags were provided for each Núcleos de Assistência Técnica e Extensão Rural (NATE) of the Instituto Rio-Grandense do Arroz (IRGA) in the different rice-producing regions of the State (Figure 1). Forty-two seed samples were collected from non-controlled plants with ALS inhibitor herbicides, being 
individually conditioned. Each package contained seeds from a single plant and each collection point was georeferenced. Immediately after receiving the samples with the inflorescence still intact, the taxonomic identification of species of the genus Cyperus was performed by means of a weed identification manual (Lorenzi, 2014).

During the collections, a questionnaire was applied to the farmer, aiming at observing some agronomic factors that could interfere with the selection of weed resistance. Questions were related to the time of continuous rice and time with rice cultivation in the Clearfield ${ }^{\circledR}(\mathrm{CL})$ system, range of doses of the herbicide imazapyr + imazapic, major weed species occurring in the area, perception on the causes of low efficiency of weed control and occurrence of resistance in the area, management practices adopted and considered as more efficient for the management of resistance, and use of crop rotation in the areas. The results were analyzed with descriptive statistics. The data were grouped into ranges and the values presented as a percentage in graphs.

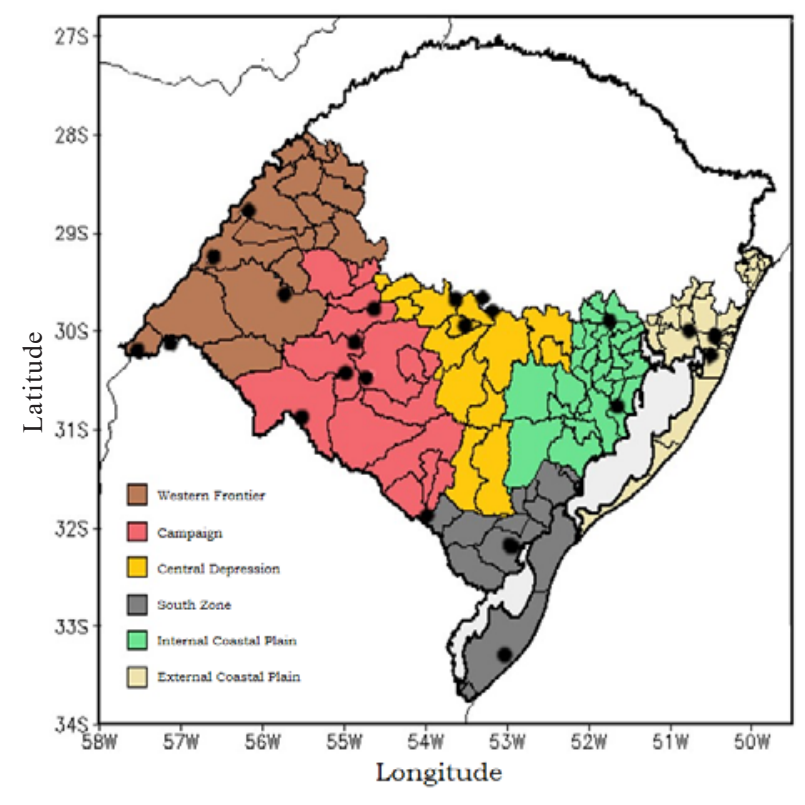

(•) Source: Adapted from GEOLIVRE (2011) - RS Thematic Maps.

Figure 1 - Representation of the rice-producing regions of the State of Rio Grande do Sul and the respective sampling sites of plants of the genus Cyperus.

For mapping regions with resistance, a greenhouse experiment was conducted from October 2015 to February 2016 to identify and classify the suspected biotypes according to their coordinates. The experimental design was a randomized block design with four replications. Each experimental unit was composed of a pot with a $0.3 \mathrm{~L}$ capacity. Previously, sowing was carried out on germitest paper soaked in water and placed in gerbox type plastic boxes, being then conditioned in biological development chambers type BOD until germination. The temperature in this period was $25^{\circ} \mathrm{C}$, with a 12 hour light photoperiod. After germination, when seedlings were in the one or two-leaf stage, two seedlings were transplanted for each pot containing sieved soil, with a subsequent thinning to keep one seedling per pot, which was stored in a greenhouse.

The treatment factor consisted of the collection sites in a single-factor scheme. Among the collected samples, 25 presented germination with plants sufficient to perform the study. When plants were in the four- to six-leaf stage, the herbicide imazapyr + imazapic was applied at a dose of $73.5 \pm 24.5 \mathrm{~g}$ a.i. ha-1 $\left(140 \mathrm{~g} \mathrm{ha}^{-1}\right)$, which is the herbicide dose present in the package leaflet.

The application was carried out with a $\mathrm{CO}_{2}$-pressurized backpack sprayer calibrated to provide an application volume of $120 \mathrm{~L} \mathrm{ha}^{-1}$ of herbicide solution and equipped with fan-type spray tips 110.01 with air injection. The analyzed variable was visual control at 30 days after treatment (DAT), using a percentage scale, where 0 and 100 corresponded to the absence of injury and death of plants, respectively. Biotypes with control lower than $50 \%$ were considered resistant, i.e., they remained alive 30 days after herbicide spraying. Subsequently, a binary scale was adopted to describe the cases of resistance and susceptibility to herbicides.

The obtained data were analyzed in a binary scale, where 0 represented plant death and 1 its survival, indicating the biotype susceptibility and resistance. For the cartographic representation of mapping of the occurrence sites of resistant biotypes, a mask was created for the State of RS using the tool GrADS (The Grid Analysis and Display System) version 2.0 (Brian Doty and the Institute of Global Environment and Society, Calverton, MD, USA), based on the control scale. 


\section{RESULTS AND DISCUSSION}

Questionnaire analysis allowed inferring that most of the farmers in places where seeds of plants of the genus Cyperus were collected have cultivated rice for more than six consecutive years (Figure 2A) and that 38\% of them have cultivated Clearfield ${ }^{\circledR}(\mathrm{CL})$ rice in the area (Figure 2B). This denotes the high selection pressure to ALS inhibitors in the areas, as observed in soybean crops of RS, where the majority of farmers have cultivated glyphosate-resistant soybean and used this herbicide for weed management in the area for more than seven consecutive years (Ulguim et al., 2017).

(A)

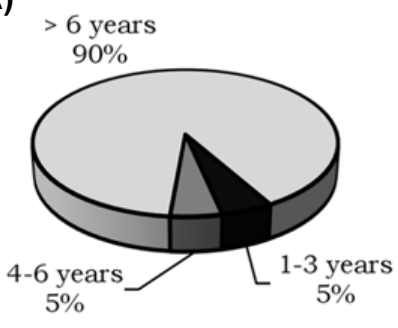

(B)

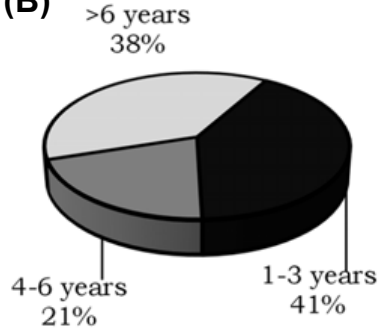

(C)

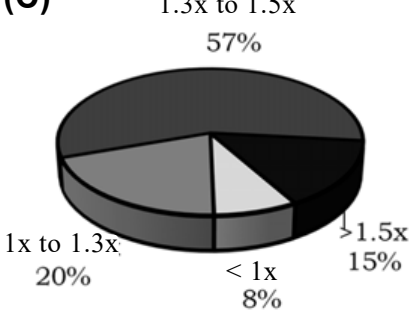

Figure 2 - Time of continuous cultivation of irrigated rice (A), rice under the Clearfield ${ }^{\circledast}$ system (B), and doses of imazapyr + imazapic ( $\mathrm{x}$ the registered dose) $(\mathrm{C})$ in the sampling areas of plants of the genus Cyperus in Rio Grande do Sul.

Regarding herbicide dose, $92 \%$ of the farmers use doses higher than the registered dose, which also increases the herbicide selection pressure (Figure 2C). Herbicide dose interferes with the selection of resistant biotypes, even in underdoses, with a change in selection time, as observed for the population of Lolium rigidum, resistant to the herbicide glyphosate and selected after three cycles (Busi and Powles, 2009). Overdoses, as observed in this study, can promote a high selection pressure and accelerate resistance evolution, in addition to selecting plants with a higher degree of resistance due to changes in a single gene. On the other hand, polygenic resistance can occur when sublethal doses are applied, selecting more tolerant plants within a population, as well as when the selection agent is repeatedly used for several generations (Busi et al., 2013). The use of herbicide registration dose was indicated by soybean and cotton producers and is recommended as one of the most important factors for weed management, aiming at the reduction of resistance cases (Riar et al., 2013b).

In the irrigated rice crop in Brazil, there are ten herbicide-resistant weed species, three of them of multiple resistance (Heap, 2018). In this study, $80 \%$ of the farmers reported that the main species present in the fields are ricegrass (Echinochloa sp.) and weed rice (Oryza sativa), accounting for about $80 \%$ of the problems (Figure 3A). Plants of the genus Cyperus appeared in $6 \%$ of the reports, denoting that the problem of these species is still in the initial phase in the fields of RS (Figure 3A). In this case, the understanding of characteristics that favor the increase of the frequency of occurrence of these plants and, mainly, the perception of the reasons that generate a low control efficiency is essential for the correct resistance characterization.

(A)

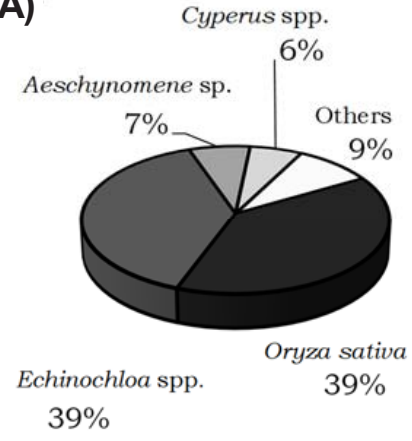

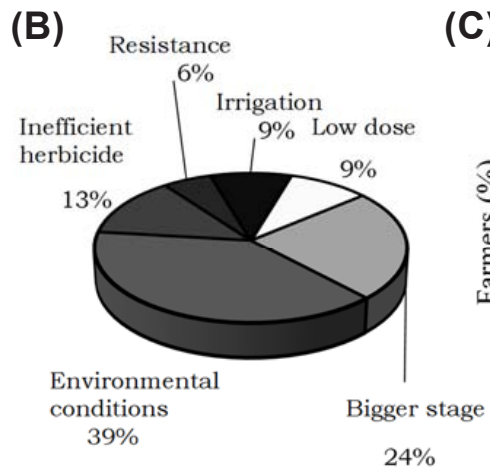

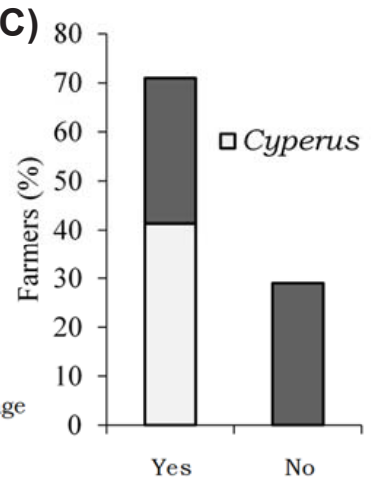

Figure 3 - Weed species reported as first or second in occurrence (A), reasons pointed out by farmers for a low control efficiency (B), and percentage of farmers who believe there is resistance in their area of cultivation and reports of resistance of plants of the genus Cyperus (C) in sample collection areas of Rio Grande do Sul. 
Farmers reported that the lack of favorable environmental conditions, target in an advanced stage of development, and use of non-action herbicides on certain targets are the main reasons related to the low efficiency of weed control cited as a problem (Figure 3B), but these conditions restrict the management and increase selection pressure on the same mechanisms of action. Factors related to topography, environmental conditions, soil moisture, and agronomic practices such as soil tillage and crop rotation influence the effectiveness of weed management practices, promoting alternation of the prevalence of certain species in specific regions (Cardina et al., 2002), thus reducing the selection pressure and herbicide use.

From the total of respondents, only $6 \%$ of the farmers pointed the resistance as a reason for control failures and problem in weed management in production areas (Figure 3B) although about $70 \%$ of them reported resistance in their production areas (Figure $3 \mathrm{C}$ ). Thus, it is necessary to reinforce the need for knowledge of the cultivation area by farmers since management practices to be adopted should be dependent on the species predominant in the site and mainly the occurrence or not of cases of resistance.

About $40 \%$ of the farmers reported the occurrence of plants of the genus Cyperus with resistance in their areas (Figure 3C). This result is similar to that observed in areas of resistance to glyphosate, where farmers considered herbicide-resistant weeds to exist in their area, but did not consider the problem to be worsening (Prince et al., 2012). For cases of resistance of the genus Cyperus in RS, producers have had a good perception of this problem and should adopt measures for weed management. In this context, farmers reported the adoption of several strategies with the aim of managing the resistance in their properties, especially crop rotation, the association of other herbicides, and herbicide rotation (Figure 4A).

(A)

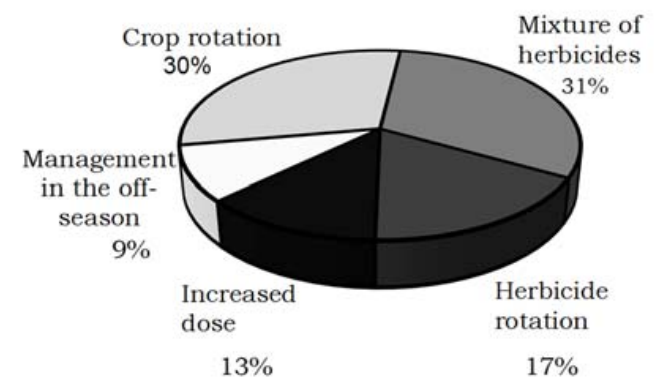

(B)

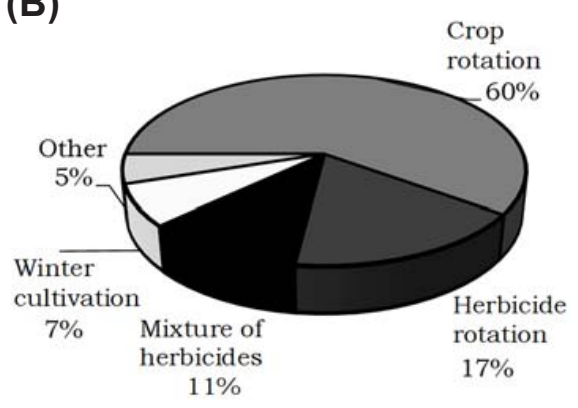

Figure 4 - Practices adopted by farmers aiming at managing resistant weeds (A) and practices that they believe to be more efficient to prevent new cases of resistance (B) in sample collection areas of plants of the genus Cyperus in Rio Grande do Sul.

In general, the strategies most cited by farmers are those frequently recommended for weed resistance management, especially the use of more than one mechanism of herbicide action, which is considered one of the most effective practices (Riar et al., 2013b) and may assist in reducing the frequency of resistant biotypes (Neve et al., 2011; Norsworthy et al., 2012). However, a significant part of the producers (13\%) mentioned increasing herbicide dose as a tool to manage resistant weeds (Figure 4A), which is not a recommended strategy that may select high-resistance alleles in the weed population.

Practices to reduce seed production of resistant weeds are strongly recommended for their management, avoiding the substitution of the weed flora and the dominance of resistant biotypes. In this sense, there was no report of the use of any type of tool to prevent reinfestation of the seed bank (Figure 4). According to Riar et al. (2013b), practices to avoid seed production, such as the elimination of resistant weeds through manual weeding during the season and off-season are widely adopted in soybean production areas in the central-south region of the United States. For this, the farmers needed to be educated on the basis of cultural and mechanical preventive practices in weed management (Norsworthy, 2003; Riar et al., 2013a).

One of the main causes of the non-adoption of certain recommended management practices to avoid resistance is the lack of information by farmers, mainly on the factors that interfere with the selection pressure. In this sense, the farmers interviewed in this study, when questioned 
about which practice they considered most important to mitigate resistance cases, mostly reported crop rotation as the main method (Figure 4B). This result is in contrast with those observed since only about $30 \%$ use this strategy with the objective of resistance management (Figure 4A), showing in this case that the farmers are aware of the factors that interfere with the resistance selection pressure in RS, but in many cases, they do not use it. This information is in accordance with the data found in the literature, which show that strategies for management and mitigation of resistance are well understood by farmers even though few have been implementing them (Beckie and Hall, 2014), mainly under the economic point of view (Edwards et al. al., 2014). In most cases, farmers have adopted the most convenient and economical management practices until a critical event promotes paradigm breakdown (Burgos et al., 2013).

For irrigated rice fields, where samples of plants used in this study were collected, a low crop rotation index was observed and, when present, little time was spent in the area, generally reinforcing the high selection pressure of resistance (Figure 5). However, there are few crop rotation alternatives for irrigated rice due to risks of water overflow from rice growing areas, with soybean (Glycine max) being the most widely used option.

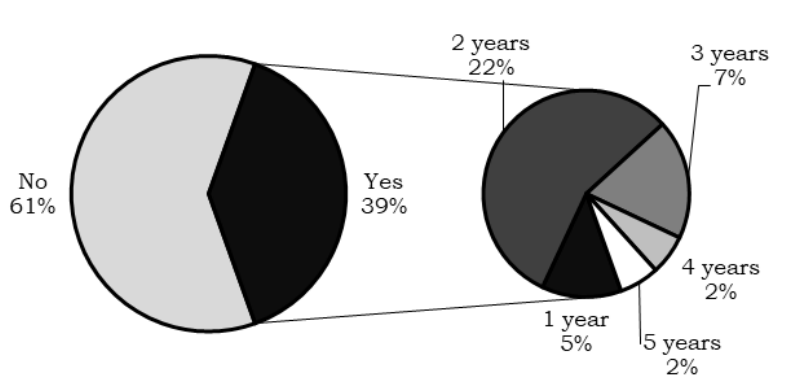

Figure 5 - Percentage of farmers that perform crop rotation with soybean and the period with this practice in sample collection areas of plants of the genus Cyperus in Rio Grande do Sul.

The observed results point to several agronomic factors that interfere with herbicide selection pressure, which may explain the high number of weed resistance cases in irrigated rice production areas in RS. In addition, reports of the occurrence of resistance by farmers indicate that the problem of managing plants of the genus Cyperus is emerging and the places of occurrence and predominance of species in the areas should be known.

The study on the mapping of the occurrence of plants of the genus Cyperus in $\mathrm{RS}$ resulted in the collection of different species, characterized as control failures in the

fields, being: C. difformis, C. esculentus, C. ferax, and C. iria, which represented $76 \%$ of the samples (Table 1). Among the resistant biotypes of Cyperus, $40 \%$ of the tested samples showed resistance to the herbicide imazapyr + imazapic (Table 1), which corroborates the data of reports of farmers who believe that there are plants of this genus with resistance in their areas (Figure 3C). In addition, among the six rice-growing regions in the State, only in the South Zone there were no cases of resistance (Table 1) although it is not possible to state that there are no resistant biotypes in this cultivation region. This fact indicates a relatively high degree of infestation of resistant biotypes in RS even though few farmers have reported these plants as a problem in their areas (Figure 4A).

The resistance of biotypes of Cyperus in Brazil was reported for the herbicides bispyribacsodium, imazapic, imazethapyr, penoxsulam, and pyrazosulfuron-ethyl, involving more than one chemical group of the mechanism of action (Heap et al., 2018), hampering and reducing the chemical control alternatives of the species. Therefore, it is important to know the places of occurrence of resistant biotypes in order to adopt auxiliary management measures.

In general, the regions with the highest occurrence of resistance for populations of plants of the genus Cyperus tested in this study are the Western Frontier, Central Depression, and the Internal and External Coastal Plains (Figure 6). These regions are the same as those observed for populations of Echinochloa spp., resistant to the herbicide quinclorac, cultivated with the Clearfield $^{\circledR}$ technology (Andres et al., 2007), demonstrating the impact of the management of these areas on resistance evolution or selection resistant weeds.

The results observed in this study allow inferring that the continuous rice cultivation in the CL system and with high herbicide doses, together with the low adoption of crop rotation, favors the high selection pressure of resistant weed biotypes in irrigated rice areas of RS. Even though it is not mentioned as one of the main weeds, almost half of the samples collected from plants of 
ULGUIM, A.R. et al. Resistance mapping of the genus Cyperus in Rio Grande do Sul and selection pressure analysis

Table 1 - Description, rice-producing regions, and geographical coordinates of plant biotypes of the genus Cyperus with the respective species and control at 30 days after imazapyr + imazapic application at a dose of $73.5+24.5 \mathrm{~g}^{2} .1$. ha ${ }^{-1}$

\begin{tabular}{|c|c|c|c|c|c|}
\hline Biotype & Region & $\begin{array}{c}\text { Latitude } \\
\text { (S) }\end{array}$ & $\begin{array}{l}\text { Longitude } \\
\text { (W) }\end{array}$ & Specie & Control \\
\hline 3.1 & Internal Coastal Plain & $30^{\circ} 46^{\prime} 03.23^{\prime \prime}$ & 5139'32.99”' & C. iria & $0^{(1)}$ \\
\hline 6.1 & Central Depression & $29^{\circ} 41^{\prime} 20.1^{\prime \prime}$ & $53^{\circ} 38^{\prime} 45.5^{\prime \prime}$ & C. iria & 0 \\
\hline 8.1 & Western Frontier & $28^{\circ} 47^{\prime} 05.6^{\prime \prime}$ & $56^{\circ} 10^{\prime} 07.2^{\prime \prime}$ & C. iria & 0 \\
\hline 9.1 & Western Frontier & $29^{\circ} 38^{\prime} 72.2^{\prime \prime}$ & $55^{\circ} 44^{\prime} 26.9^{\prime \prime}$ & C. difformis & 0 \\
\hline 11.1 & South Zone & $32^{\circ} 11^{\prime} 23.2^{\prime \prime}$ & $52^{\circ} 58^{\prime} 47.55^{\prime \prime}$ & C. iria & 1 \\
\hline 11.2 & South Zone & $32^{\circ} 12^{\prime} 18.2^{\prime \prime}$ & $52^{\circ} 57^{\prime} 36.69^{\prime \prime}$ & C. iria & 1 \\
\hline 11.3 & South Zone & $32^{\circ} 12^{\prime} 04.39^{\prime \prime}$ & $52^{\circ} 56^{\prime} 57^{\prime \prime}$ & C. iria & 1 \\
\hline 12.2 & Western Frontier & $30^{\circ} 12^{\prime} 08^{\prime \prime}$ & $57^{\circ} 32^{\prime} 58^{\prime \prime}$ & C. esculentus & 1 \\
\hline 12.3 & Western Frontier & $30^{\circ} 08^{\prime} 18.30^{\prime \prime}$ & $57^{\circ} 08^{\prime} 17.40^{\prime \prime}$ & C. iria & 1 \\
\hline 14.1 & Campanha & $29^{\circ} 47^{\prime} 30^{\prime \prime}$ & $54^{\circ} 38^{\prime} 08^{\prime \prime}$ & C. iria & 1 \\
\hline 15.1 & External Coastal Plain & $30^{\circ} 00^{\prime} 60.4^{\prime \prime}$ & $50^{\circ} 46^{\prime} 55.1^{\prime \prime}$ & C. iria & 1 \\
\hline 16.3 & South Zone & $33^{\circ} 18^{\prime} 23^{\prime \prime}$ & $53^{\circ} 02^{\prime} 69^{\prime \prime}$ & C. esculentus & 1 \\
\hline 19.2 & Western Frontier & $29^{\circ} 15^{\prime} 46.7^{\prime \prime}$ & $56^{\circ} 36^{\prime} 47.6^{\prime \prime}$ & C. iria & 0 \\
\hline 21.2 & External Coastal Plain & $30^{\circ} 15^{\prime} 28^{\prime \prime}$ & $50^{\circ} 30^{\prime} 35^{\prime \prime}$ & C. difformis & 1 \\
\hline 22.1 & Campanha & $30^{\circ} 29^{\prime} 71^{\prime \prime}$ & 544'39”' & C. iria & 1 \\
\hline 22.2 & Campanha & $30^{\circ} 07^{\prime} 10^{\prime \prime}$ & $54^{\circ} 52^{\prime} 26^{\prime \prime}$ & C. iria & 0 \\
\hline 22.3 & Campanha & $30^{\circ} 26^{\prime} 05^{\prime \prime}$ & $54^{\circ} 59^{\prime} 24^{\prime \prime}$ & C. iria & 1 \\
\hline 24.2 & Campanha & $31^{\circ} 53^{\prime} 32.89^{\prime \prime}$ & 5359’03”' & C. esculentus & 1 \\
\hline 28.1 & Internal Coastal Plain & $29^{\circ} 54^{\prime} 18^{\prime \prime}$ & $51^{\circ} 45^{\prime} 37^{\prime \prime}$ & C. iria & 0 \\
\hline 30.3 & Campanha & $30^{\circ} 53^{\prime} 27^{\prime \prime}$ & $55^{\circ} 31^{\prime} 58^{\prime \prime}$ & C. ferax & 1 \\
\hline 32.1 & External Coastal Plain & $30^{\circ} 03^{\prime} 48.3^{\prime \prime}$ & $50^{\circ} 27^{\prime} 29.7^{\prime \prime}$ & C. iria & 0 \\
\hline 32.2 & External Coastal Plain & $30^{\circ} 04^{\prime} 07^{\prime \prime}$ & $50^{\circ} 27^{\prime} 20.00^{\prime \prime}$ & C. iria & 0 \\
\hline 36.3 & Central Depression & $29^{\circ} 57^{\prime} 23^{\prime \prime}$ & $53^{\circ} 31^{\prime} 46^{\prime \prime}$ & C. iria & 0 \\
\hline 37.2 & Central Depression & $29^{\circ} 40^{\prime} 48.62^{\prime \prime}$ & $53^{\circ} 18^{\prime} 43.74^{\prime \prime}$ & C. iria & 1 \\
\hline 37.3 & Central Depression & $29^{\circ} 48^{\prime} 39.66^{\prime \prime}$ & $53^{\circ} 11^{\prime} 44.96^{\prime \prime}$ & C. iria & 1 \\
\hline
\end{tabular}

(1) Binary scale, where 1 represents plant death (susceptibility) and 0 represents its survival (resistance).

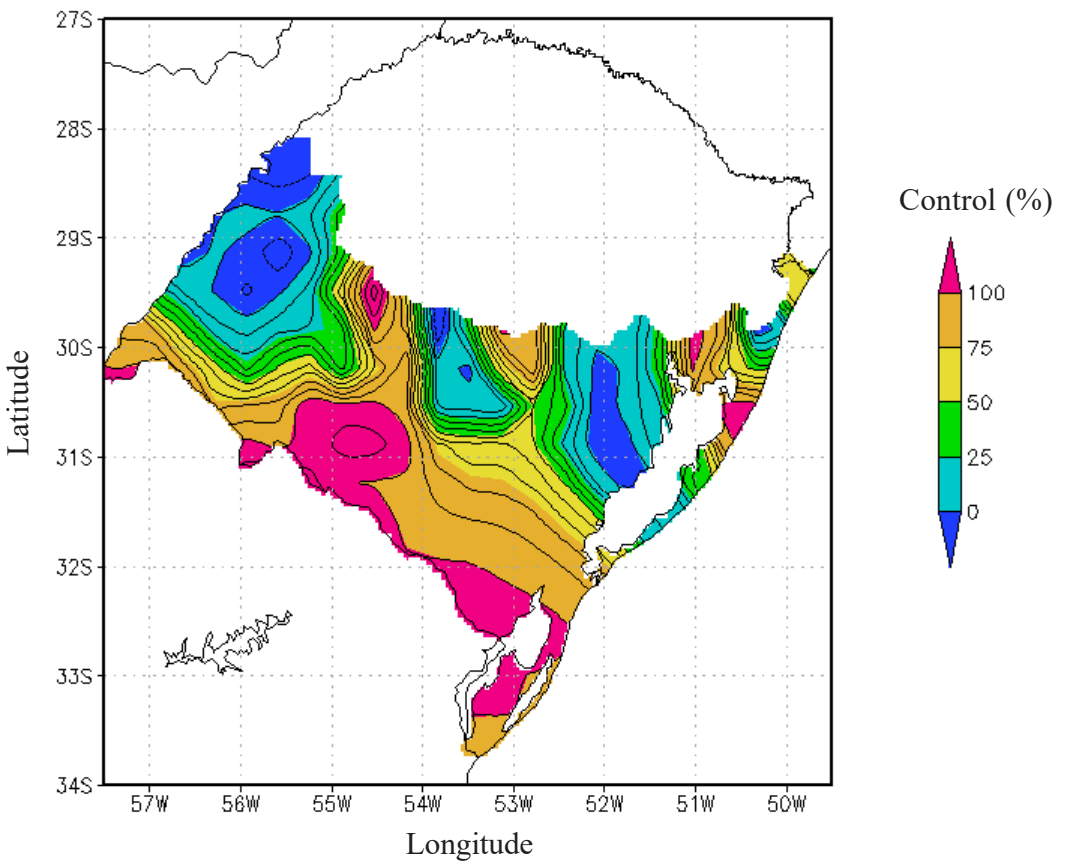

Figure 6 - Map of control response (\%) of plant biotypes of the genus Cyperus at 30 days after imazapyr + imazapic application at a dose of $73.5+24.5 \mathrm{~g}$ a.i. ha-1. 
the genus Cyperus are resistant to ALS inhibitors, distributed mainly in four growing regions. Thus, alternatives should be adopted for weed management, as well as for reducing selection pressure, in order to reduce yield losses and prevent the problem from spreading in irrigated rice production areas of RS.

\section{REFERENCES}

Agostinetto D, Westendorff NR, Ulguim AR, Nohatto MA, Avila LA. Yield loss and economic thresholds of yellow nutsedge in irrigated rice in function of cultivars. Biosci J. 2016;32(3):588-96.

Andres A, Concenço G, Melo PTBS, Schmidt M, Resende RG. Detecção da resistência de capim-arroz (Echinochloa sp.) ao herbicida quinclorac em regiões orizícolas do sul do Brasil. Planta Daninha. 2007;25(1):221-6.

Beckie HJ, Hall LM. Genetically-modified herbicide-resistant (GMHR) crops a two-edged sword? An Americas perspective on development and effect on weed management. Crop Prot. 2014;66:40-5.

Burgos NR, Tranel PJ, Streibig JC, Davis VM, Shaner D, Norsworthy JK, et al. Review: confirmation of resistance to herbicides and evaluation of resistance levels. Weed Sci., 2013;61:4-20.

Busi R, Neve P, Powles SB. Evolved polygenic herbicide resistance in Lolium rigidum by low-dose herbicide selection within standing genetic variation. Evol Appl. 2013;6:231-42.

Busi R, Powles SB. Evolution of glyphosate resistance in a Lolium rigidum population by glyphosate selection at sublethal doses. Heredity. 2009;103:318-25.

Cardina J, Herms CP, Doohan DJ. Crop rotation and tillage system effects on weed seedbanks. Weed Sci. 2002;50:448-60.

Chauhan BS, Johnson DE. Responses of rice flatsedge (Cyperus iria) and barnyardgrass (Echinochloa crus-galli) to rice interference. Weed Sci. 2010;58:204-8.

Chapinotto DM, Schaedler CE, Fernandes JPS, Andres A, Lamego FP. Cross-resistance of rice flatsedge to als-inhibiting herbicides. Planta Daninha. 2017;35:1-12.

Edwards CB, Jordan DL, Owen MD, Dixon PM, Young BG, Wilson RG, et al.. Benchmark study on glyphosate-resistant crop systems in the United States. Economics of herbicide resistance management practices in a 5 year field-scale study. Pest Manage Sci. 2014;70(12):1924-9.

GEOLIVRE. Mapas temáticos RS. [acessado em: 03 abr. 2011]. Disponível em: http://www.geolivre.rs.gov.br/.

Heap I. Internacional survey of herbicide resistant weeds. [acessado em: 20 mar. 2018]. Disponível em: http://www.weedscience.org.

Kissmann KG. Plantas infestantes e nocivas. $3^{\text {a }}$.ed. São Paulo: Basf Brasileira; 2007.

Lorenzi H. Manual de identificação e controle de plantas daninhas: plantio direto e convencional. $7^{\text {a }}$. ed. Nova Odessa: Instituto Plantarum; 2014. 379p.

Neve P, Norsworthy JK, Smith KL, Zelaya IA. Modeling glyphosate resistance management strategies for almer amaranth (Amaranthus palmeri) in cotton. Weed Technol. 2011;25(3):335-43.

Norsworthy JK, Ward SM, Shaw DR, Llewellyn RS, Nichols RL, Webster TM, et al. Reducing the risks of herbicide resistance: best management practices and recommendations. Weed Sci. 2012;60:31-62.

Norsworthy JK. Use of soybean production surveys to determine weed management needs of South Carolina farmers. Weed Technol. 2003;17:195-201.

Prince JM, Shaw DR, Givens WA, Newman ME. Benchmark study: II. a 2010 survey to assess grower awareness of and attitudes toward glyphosate resistance. Weed Technol. 2012;26(3):531-5.

Riar DS, Norsworthy JK, Steckel LE, Stephenson DO. Adoption of best management practices for herbicide-resistant weeds in Midsouthern United States cotton, rice, and soybean. Weed Technol. 2013b;27(4):788-97.

Riar DS, Norsworthy JK, Steckel LE, Stephenson DO, Eubank TW, Scott RC. Assessment of weed management practices and problem weeds in the Midsouth United States - soybean: A consultant's perspective. Weed Sci. 2013a;27(3):612-22.

Ulguim AR, Agostinetto D, Vargas L, Silva JDG, Silva BM, Westendorff NR. Agronomic factors involved in low-level wild poinsettia resistance to glyphosate. Rev Bras Cienc Agr. 2017;12:51-9. 